\title{
The Situations of Sole Proprietorship, E-Commerce Entrepreneurs and Trends in Their E-commerce: A Case Study in Thailand
}

\author{
Pattarawadee Permwanichagun ${ }^{1}$, Sumeth Kaenmanee ${ }^{1}$, Aree Naipinit ${ }^{1} \&$ Thongphon Promsaka Na Sakolnakorn $^{2}$ \\ ${ }^{1}$ Faculty of Management Science, Khon Kaen University, Khon Kaen, Thailand \\ ${ }^{2}$ Institute for Peace Studies, Prince of Songkla University, Hat Yai Campus, Thailand \\ Correspondence: Pattarawadee Permwanichagun, Faculty of Management Science, Khon Kaen University, Khon \\ Kaen 40002, Thailand. E-mail: pattarawadee999@hotmail.com
}

\author{
Received: June 16, 2014 Accepted: September 4, 2014 Online Published: October 30, 2014 \\ doi:10.5539/ass.v10n21p80 \\ URL: http://dx.doi.org/10.5539/ass.v10n21p80
}

\begin{abstract}
The aim of this study is to examine the situations of sole proprietorship, e-commerce entrepreneurs and trends in their e-commerce. This study uses a mixed-method quantitative and qualitative approach for collecting the data. The study finds that most sole proprietorships in e-commerce are owned females between 31 and 40 years old who are educated with a Bachelor's degree (63.16\%) and draw an income of 40,001-50,000 bahts per month (approximate \$1 USD = 33 bahts). Most of these sole proprietorships $(66.59 \%)$ are located in the central part of Thailand. These entrepreneurs spend more than eight hours a day on their businesses and supply their products by themselves. However, most of the problems faced by these sole proprietorship, e-commerce entrepreneurs involve the cost for investment in the business and the knowledge that is required in order to be an entrepreneur. Nevertheless, the trend toward sole proprietorship, e-commerce entrepreneurs in Thailand will increase with the adaptation of mobile-commerce in Thai society.
\end{abstract}

Keywords: sole proprietorship, e-commerce, Thailand, entrepreneur

\section{Introduction}

Information technology (IT) is important in business, particularly the Internet, which directly connects producers and customers (Harpaz, 2002) who can communicate quickly and clearly in real time (Fillis \& Wanger, 2005). According to 2012 statistics, Internet users totaled about 2,405 million, or $34.27 \%$ of the world's population (Internet World Usage and Population Statistics, 2012). In Asia, Internet users totaled about 1,076 million, or $44.74 \%$ of the world's population. These users are increasing in line with opportunities to develop business networks. Entrepreneurs who are selling goods in their shops can now use IT to sell even more online (Damanpour, 2001; Santos, 2003) as their marketing increases from local to worldwide, in Thailand The number of Internet domain names worldwide in 2012 was about 63,705, Thailand has about 20 million Internet users, which constitutes approximately $30 \%$ of the total population. More than $57 \%$ of these users shop online (National Electronics and Computer Technology Center, 2012). This way of doing business is known as electronic commerce (e-commerce). At present, e-commerce influences new entrepreneurs in Thailand because many businesses are now using IT to increase their sales (National Statistics, 2012). The capital investment factor is one reason for entrepreneurs' decision to use IT in their business lines.

Thailand's government implemented policies to expand e-commerce, such as IT and communication strategy planning (vol. II) during 2009-2013 and proposed e-commerce as a major strategy for commercial and social-economic innovation. It also invested in IT structural and industrial bases. E-commerce included the countrywide development of social media and network (Office of the Permanent Secretary of Ministry of Information and Communication Technology, 2012). For the IT framework of policies between 2011 and 2020 , the government has strategies for development planning, such as 1) the development of an infrastructure for IT and communications, 2) the development of human resources in IT and communications, 3) the use of innovative IT and communication development for administrative needs and management of the government, 4) the use of IT and communications to boost Thailand's production, 5) the development and application of IT and communications for balancing the lives of the Thai people and 6) the development and application of IT and communications to support socio-economic growth and environmentally friendly activities (Ministry of Information and Communication Technology, 2012). 
A sole proprietorship, as reported in the Ministry of Foreign Affairs' business handbook (2011), is a business with a single owner with unlimited liability. Thus, a sole proprietorship is a small organization whose size makes it difficult to convince customers of its merits. In the business of e-commerce, the number of sole proprietorships has increased too fast; such businesses have too many products to promote via the Internet. Ratprasatporm and Thienpreecha (2002) suggested that the businesses started by foreigners as sole proprietorships more than 10 years ago must achieve a track record before gaining a commercial registration certificate by government agencies.

However, sole proprietorship, e-commerce entrepreneurs in Thailand started by making low-cost investments and launching a small business without registering for a license or certificate. In addition, Thai entrepreneurs have many questions about the direction and trend of business and how to improve themselves by using e-commerce to manage business. This paper seeks to evaluate the research questions pertaining to the situations of sole proprietorship, e-commerce entrepreneurs, and evaluate the trends in their e-commerce. Therefore, this study will lead to guidelines that sole proprietorship e-commerce entrepreneurs may use to enhance the development their business.

\section{Objective}

To examine the situations of sole proprietorship, e-commerce entrepreneurs and trends in their e-commerce.

\section{Literature Reviews and Conceptual Framework}

\subsection{The Sole Proprietorship}

A sole proprietor is a person who owns and run his or her business alone (IRS, 2014). A sole proprietor is a person who runs his or her own business and is personally responsible for its debts; such a business classification is popular because it is easy to set up and carries a low cost for a first investment. A sole proprietor only registers his or her business name for local licenses; then, after that, the business is ready to be run (Entrepreneurs, 2005). However, sole proprietors have another definition. For example, a sole proprietorship is a one-person entity that is not registered with the state in order to exist. It is easy to set up, it easily avoids local registration requirements, does not carry a business license, and can avoid paying taxes on income (Inc., 2010). In addition, researchers conclude that a sole proprietorship means that the owner of a business is just one person; thus, its coverage of management and administration is limited to small- and medium-sized business management.

\subsection{E-commerce Business}

Technology acquisition can improve a firm's performance (Kiyota \& Okazaki, 2005). Technology management can help the owner of a business to meet his or her needs and increase the venture's capacity by volume and variety of products (Brown, 2001). E-commerce is meant to be a conduit of economic activity by using the Internet or via online transactions; for example; the sale of goods by using an Internet-based system and by transferring money through electronic banking (Bank of Thailand, 2008). E-commerce companies or online retailers involve seeing to the demands of the customer, logistics systems, seasonal fluctuations, inventory control and management and risk management, such as lost sales, customer decline, customer satisfaction, and financial control (Patil \& Divekar, 2014). The benefit of e-commerce are that it can help entrepreneurs to be aware of day-to-day working and provide access to the working financials of the company. Further, suppliers and distributors can learn and have knowledge of selling price quotes and the goods of entrepreneurs by accessing the business' home page. Customers can also visit entrepreneurs' homepages to check selling prices, logistics, and shipment services (Reddy \& Divekar, 2014).

\subsection{Situations with E-commerce in Thailand}

The Internet and e-commerce assist in boosting the organization's performance (Feizollahi et al., 2014). Phecharaburanin (2013) reported that, at present, e-commerce is very important to Thai society, just as it is in Singapore and Japan, because the businesses can take responsibility for customers' needs. The National Economic and Social Office (2012) reported that, between 2005 and 2010, the percentage of children using the Internet by the age of six increased from $12 \%$ in 2005 to $22.4 \%$ in 2010 . At the same time, e-commerce with sole proprietorships and businesses using electronic sales channels increased $10.7 \%$ in 2005 to $16.5 \%$ in 2010 . The main types of businesses in e-commerce were fashion (30.8), e-tickets (14.8\%), books (13.3) and food and beverages (13.3\%). Almost all customers between 25 and 49 years of age (about $68.8 \%$ of the total population) spent, via e-commerce, an average of 3,000 baht per person (approximately $1 \mathrm{USD}=31.5 \mathrm{baht}$ ). Sintrakranphon (2008) explained that this modern business cannot be large-scale at this time, but it can eventually respond to customers' needs in terms of values and lifestyles. 


\subsection{Benefits of a Sole Proprietorship}

The opportunity exists for small and medium businesses with a sole proprietorship in e-commence to apply their techniques of management, such as direct control of line production and marketing (Ongsakul \& Kanitpong, 2007). In addition, Pattanakit Accounting Tax and Training (2013) described the strong points of sole proprietorship in Thailand as follows:

1) It is easy to settle a business deal. Simply register with the Department of Commercial Registration and the Revenue Department.

2) The owner of the business has the authority to make decisions in policy planning and management.

3) It is easy to revoke a business deal if money is lost or if the deal is not a suitable investment.

4) It is easy to revoke business other than with the partnership and company.

5) The lack of the need to share the benefits.

6) The laws and taxes are not concentrated as they are for other businesses.

7) The tax expense is paid by the entrepreneurs or as a private tax; thus, it is not a business tax.

E-commerce and online stores are always open, around the clock and each day of the year; even while the company is closed at night, customers can visit the company store, browse products, and place their orders (Tokokoo, 2010). The Business Research Sector (2012) reported the benefits of e-commerce to SME entrepreneurs, and the three main issues were as follows: 1) increasing the channel of marketing to deal all time and worldwide, 2) lower costs for contracts with customers and 3) widely distributed customer groups.

\subsection{Detriments of a Sole Proprietorship}

An e-commerce sole proprietorship may be comfortable for management, but it is actually difficult to manage customers because customers and entrepreneurs never have direct contact. This problem has caused the government to expand into the management of e-commerce systems (Ratprasatporn \& Thienpreecha, 2002). Many companies face difficulties in adopting e-commerce systems because e-commerce systems and this technology cannot be adopted by a firm and it carries a high cost of investment (Ali \& Kurnia, 2010). In addition, Chonkrin (2008) explained the weaknesses of sole proprietorship in Thailand as follows:

1) Most of the businesses do not have an organized system because the owner just wants to do business without any knowledge of management.

2) The situation involves increasing partnerships and investments, which is different from the sole proprietorship format.

3) There is the risk of debt because there is only one owner.

4) Business is delicate because management is run by only one person. Thus, if the owner becomes ill, the business slows or stops.

5) The business is reliable when doing transactions with large businesses or governments.

6) It is difficult to expand the business.

In addition, the obstacles of sole proprietorship using e-commerce faces problems in many countries, as Kun (2000) explains. Examples include the obstacles that arise when using e-commerce for business in China, such as a lack of knowledge and entrepreneurship skills, unsatisfactory Internet network quality, incomplete online security and confidentiality and the inability to guarantee the security of online transactions, especially in terms of the mode of payment.

\subsection{Conceptual Framework}

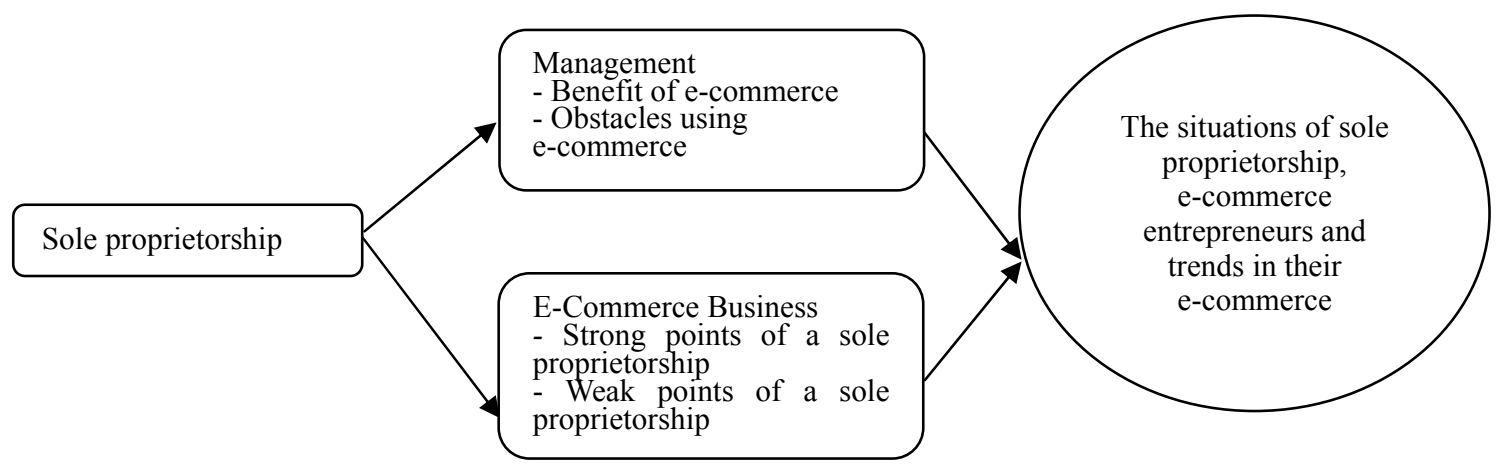

Figure 1. Conceptual framework 
From the literature reviews, researchers found that e-commerce carries both benefit and obstacles for entrepreneurship; however, it depends on the management of entrepreneurship to set up the guideline for this study. Therefore, researchers created a conceptual framework (Figure 1).

\section{Methodology}

This research effort uses a quantitative approach for collecting data in order to better understand the situations that involve sole proprietorship, e-commerce entrepreneurs in Thailand in order to discuss trends and forecasts.

\subsection{The Sample}

The study focuses on sole proprietorship, e-commerce entrepreneurs, based on information from the 1,200 questionnaires that were sent out. In total, 874 responses, or $72.83 \%$ of sole proprietorship, e-commerce entrepreneurs, were received. The researchers also interviewed three experts about e-commerce.

\subsection{Tools for Collecting Data}

After collecting the sole proprietorship, e-commerce entrepreneurs' questionnaires, the information was used to structure interviews for collecting data from experts.

\subsection{Scope of Content}

In the research, the focus was on sole proprietorship, e-commerce entrepreneurs, and the collected information was used for considering the situation of the sole proprietors and their problems in forecasting the trends in their businesses.

\subsection{Data Analysis}

The analysis focused on the situation of sole proprietorship, e-commerce entrepreneurs, and its descriptive statistical analysis was combined with data from expert interviews for reflections on the opportunities and gaps in the business that could be used for forecasting the trends of the e-commerce conducted by the sole proprietorship, e-commerce entrepreneurs. In addition, researchers also performed regression analysis to study the success factors in the business of sole proprietorship. SWOT analysis was then applied to study the strengths, weaknesses, opportunities, and threats that affect the scenario.

\section{Results and Discussion}

The general information about sampling is that this research study submitted 1,200 questionnaires to sole proprietorship, e-commerce entrepreneurs, and the response and feedback to the researcher consisted of 874 questionnaires, or $72.83 \%$ of the original sampling.

\subsection{Gender of Sampling}

Most sole proprietorships in e-commerce are owned by females (67.39\% versus $32.61 \%$ of males), so the results indicate that women like to select products and order products via the Internet (Rodgers \& Harris, 2003). Schimmerl (2005) explained that women's e-commerce increased 2\% in 1998-2000 and will continue to increase because the of women's behavior as shoppers. A sole proprietorship will remain open for business if women customers are satisfied. Similarly, Ortega et al. (2008) explained that gender influences the type of e-commerce businesses, as women have more power as shoppers than men. Therefore, women are the main channel for e-commerce and the target group.

\subsection{Age and Status of Sole Proprietorship E-commerce}

In order, the age ranges of the samples were from 31 to 40 years (44.28\%), 41 to 51 years $(31.24 \%), 21$ to 30 years (16.59), and less than 20 years (6.52\%). Their marital status was $56.41 \%$ married, $39.13 \%$ single, $2.4 \%$ divorced, and $2.06 \%$ separated. Given that so many sole proprietorships in e-commerce belong to people of working age, this represents a big change in Thai society and shows how these entrepreneurs are adapting to modern business. MacGregor and Vrazalic (2004) explained the phenomenon by stating that entrepreneurs in modern business are adopting technology in response to the lifestyles of customers. Chammanee (2011) reported that the ages of customers who order products electronically range from 31 and 40, so the age ranges are similar between the entrepreneurs and customers, which increases the possibility that the producers will use the customers' needs as the basis for their decision to start a business. The data present in the age range of 31-40 years indicates that it is a major group of sole proprietorships.

\subsection{Education of Proprietorship E-commerce in Thailand}

The educational level of the sole proprietorship, e-commerce entrepreneurs is as follows: bachelor's degree, $63.16 \%$; post-graduate, $18.42 \%$; diploma, $14.19 \%$; high school, $1.49 \%$; primary school, $1.49 \%$; and below 
primary school, $0.69 \%$. Almost all sole proprietorship, e-commerce entrepreneurs in Thailand have a bachelor's degree, so this study differs from the work of Mansor and Abidin (2010), who stated that, in Malaysia, the comparable percentage for a bachelor's degree is about $22.5 \%$, with almost $45 \%$ of the entrepreneurs obtaining the Sijil Pelajaran Malaysia (SPM), which is the Malaysian Certificate of Education. The most major educational group is the bachelor's degree, so it is apparent that one's level of education influences his or her choice to launch a sole proprietorship. A related report from the Electronic Transaction Department Agency (2014) stated that, among those who hold bachelor's degrees, $60 \%$ use the Internet, so they're spending more than 3.23 hours per day.

\subsection{Income of Sole Proprietorship E-commerce in Thailand}

Among sole proprietorships in Thailand, 36.16\% generate an income of 40,001-50,000 baht per month (\$1 USD $=33 \mathrm{baht}$ ); $31.24 \%$ generate $30,001-40,000 \mathrm{baht} ; 13.50 \%$ generate more than $50,000 \mathrm{baht} ; 10.53 \%$ generate 20,001-30,000 baht; $4.92 \%$ generate less than 10,000 baht per month; and 3.66\% generate 10,001-20,000 baht. According to the Kasikron Research Center (2013), the opportunities for sole proprietorship e-commerce in Thailand are increasing, as is the revenue. However, the income of sole proprietorship, e-commerce entrepreneurs is high, if compared to the 300-baht minimum wage in Thailand.

\subsection{Type of Business with Sole Proprietorship E-commerce in Thailand}

The sole proprietorships in e-commerce in the survey are classified by business as follows: 1) fashion, $42.56 \% ; 2$ ) computer electronics, $21.05 \%$; 3) hotels and resorts, $7.21 \%$; 4) furniture, $6.06 \%$; 5) food and food products, $4.69 \%$; 6) motor vehicles, $4.00 \%$; 7) printing and office components, $3.32 \%$; 8) medical and health, 3.20\%; 9) education, $2.97 \%$; 10) agriculture, $2.06 \%$; 11) properties, $1.06 \%$; 12) logistics $0.69 \%$; and 13 ) insurance, $0.57 \%$.

\subsection{Experience of the Sole Proprietorship with E-commerce}

In the survey, the type of sole proprietorships can be divided into the entrepreneurs doing business online (65.22\%) and entrepreneurs doing business online combined with a shop (34.78\%). The business experience of the sole proprietors varied from $61.10 \%$ with more than five years to $29.29 \%$ with two to five years, to $9.61 \%$ with less than two years. Keawkityphong (2013) stated that the sole proprietorships in e-commerce in Thailand are good at adapting to technology so, at present, they are transforming e-commerce into $\mathrm{m}$-commerce $(\mathrm{m}=$ mobile phone) and providing e-service to m-commerce users.

\subsection{The Location of Sole Proprietorship with E-commerce}

Most of these sole proprietorships are located in the central part of Thailand (66.59\%), as well as in the northeast region $(16.25 \%)$, the southern part $(6.52 \%)$, the eastern part $(3.32 \%)$ and the western part $(2.97 \%)$. Uphatumwiphanon (2012) made a strong point that, while e-commerce is not related to the actual location of a shop, location is still important for logistics and for distributing the products to the customers. This is why most of the entrepreneurs are located in the central part of the country. At present in Thailand, it is important to develop logistics to transfer products via air, train, car and ship.

\subsection{Work Hours}

Most sole proprietors work more than eight hours per day (48.05\%), the next group works five to eight hours per day $(44.51 \%)$, and others work one to four hour per day (7.44\%). These times worked by sole proprietors are not specific because they are primarily contacted by e-mail and post boxes on the Internet.

\subsection{Production Supply}

The sole proprietors provide most of their products by themselves $(79.18 \%) ; 14.30 \%$ are trademarked, so the company has production support, and $6.52 \%$ are family products. With many sole proprietorships having a contract with a trademark, they do not struggle with the supply chain. However, the problem with the production supply in Thailand is the customers' confidence in sole proprietorships.

\subsection{Decisions to Select Production}

In a sole proprietorship, products are selected for many reasons: $42.22 \%$ due to the goods' value to the target group; $29.98 \%$ as a result of quality; $15.79 \%$ the fact that it is a modern product; and $12.01 \%$ due to the utility of the product. In terms of pricing, entrepreneurs consider quality $(43.36 \%)$, marketing strategies $(23.23 \%)$, competitors $(17.85 \%)$, discounts $(9.04 \%)$, and higher prices for a quality product $(6.52 \%)$.

\subsection{Trend of Circulation with the Business of a Sole Proprietorship}

As for the trend of circulation with the business of sole proprietorship, $57.89 \%$ of the respondents' circulation increased more than it did last year and speaks to a rising trend for the coming year. In contrast, $42.11 \%$ 
answered that their circulation was lower than it was during the previous year because Thailand's economic situation has a direct effect on customers' orders. It is possible that the trends will increase after Thailand changes its situation.

\subsection{Cost of the Business}

The cost of business for entrepreneurs can be classified into the following four conditions:

1) Most of the sample (64.30\%) invests more than $20 \%$ of their income in the business.

2) About $26.81 \%$ invests $16 \%-20 \%$.

3) About $7.67 \%$ invests $5 \%-10 \%$.

4) The cost of investing is higher than last year because the customer groups are increasing and there are many more channels with which to contact them.

\subsection{The Problems of Sole Proprietorship with E-commerce}

1) Not having enough money or funds that are too illiquid to make an investment $(75.06 \%)$

2) Deficient knowledge and labor quality $(11.09 \%)$

3) Deficient quality of human resources $(7.78 \%)$

4) Deficient tools and the use of older technology (4.35\%)

5) Deficient knowledge of suppliers (1.72\%)

\subsection{Competitive Environmental Effects on Success in an E-commerce Sole Proprietorship}

Table 1. Success factors in a sole proprietorship business

\begin{tabular}{lll}
\hline Item & Regression & P - value \\
\hline E-commerce has impacted business success & 0.389 & $0.031^{*}$ \\
E-commerce has influenced customer acceptance & 0.246 & 0.262 \\
The customers' acceptance has affected business success & 0.450 & $0.010^{* *}$ \\
The owner's behavior has affected business successions & 0.251 & $0.025^{*}$ \\
The owner's knowledge has affected business successions & -0.220 & 0.165 \\
Government support has affected business successions & 0.469 & $0.004^{* *}$ \\
Government policy has affected business successions & 0.121 & 0.357 \\
Competitive environment has affected business successions & 0.519 & $0.001^{* * *}$ \\
\hline
\end{tabular}

$*$ significance $\mathrm{p}<0.05 * *$ significance $\mathrm{p}<0.01 * * *$ significance $\mathrm{p}<0.001$

Table 2. A SWOT analysis of a sole proprietorship

\begin{tabular}{|c|c|}
\hline Strengths & Weakness \\
\hline $\begin{array}{l}\text { - Simple and easy to determine whether or not the } \\
\text { operator is established with knowledge capital } \\
\text { that pertains to the business. }\end{array}$ & $\begin{array}{l}\text { - The owner alone is entirely responsible for the } \\
\text { company; the operator shall be responsible for all } \\
\text { liabilities without limit. }\end{array}$ \\
\hline $\begin{array}{l}\text { - There is autonomy in the implementation of the } \\
\text { decisions in the business. }\end{array}$ & $\begin{array}{l}\text { - There is limited capital and it is difficult to find a } \\
\text { financial source of support. }\end{array}$ \\
\hline $\begin{array}{l}\text { - The business does not have to share the profits with } \\
\text { others. }\end{array}$ & $\begin{array}{l}\text { - The ability to think and manage services is poor } \\
\text { because the sole proprietorship's relationship to }\end{array}$ \\
\hline - The legal requirement of entrepreneur is simply to & \\
\hline - It is easy to close a business if it can't expand or the & $\begin{array}{l}\text { - The continuity of operations is extended so that the } \\
\text { owner must work hard in the business. }\end{array}$ \\
\hline business loses its capital. & \\
\hline $\begin{array}{l}\text { - The channel of transportation to product distribution } \\
\text { is comfortable. }\end{array}$ & \\
\hline Opportunity & Threats \\
\hline $\begin{array}{l}\text { - Everybody can develop a business as entrepreneurs } \\
\text { - The general public has knowledge in information } \\
\text { technology. }\end{array}$ & $\begin{array}{l}\text { - Customers' values change too fast. } \\
\text { - More entrepreneurs are in the business, thus creating } \\
\text { duplications. }\end{array}$ \\
\hline - The Internet is available throughout the country. & $\begin{array}{l}\text { - The government provides insufficient support, such } \\
\text { as funding and markets, to sole proprietors }\end{array}$ \\
\hline
\end{tabular}

In the result to regress the competitive environmental effects on success in an e-commerce sole proprietorship, there was a 0.001 level of significance $(\mathrm{R}=0.519)$ in the influences to business succession. Second, government-supported effects to business succession had a 0.01 level of significance $(\mathrm{R}=0.469)$. Third, the customers' acceptance had an effect on business succession with a 0.01 level of significance $(R=0.450)$. These 
results are shown in Table 1. However, the competitive environment effect includes environment-related or industrial qualities. The ability to generate profits of the business and the nature of competition in the industry has a direct bearing on the development of a competitive environment.

The researchers of this study strange point, so consider the with the components of sole proprietorship in e-commerce, and we've used SWOT analysis for distributing a different point of the sole proprietorship, so the results can be presented in Table 2 .

\section{Conclusion}

In the research, sole proprietorship e-commerce is increasing because it is an alternative business. Everyone can be an entrepreneur, so it is a modern trend of business innovation. At present in Thailand, sole proprietorships have many patterns; sometimes a sole proprietorship, e-commerce venture does not look like one (i.e., somebody simply has a trademark on Facebook or Instagram, etc.). They don't have products in stock, so they sell products as agents. Most of the sole proprietorship, e-commerce entrepreneurs in Thailand are women, so much of the business is connected with fashion. The proprietorship business attracted older workers who have a modern vision and who understand the culture and can apply and adapt it to business. Most the problems of sole proprietorship among e-commerce entrepreneurs are related to the costs of investing in a business and a lack of knowledge about running the company. Still, the trend of sole proprietorship e-commerce entrepreneurs in Thailand is rising with the adaptation of mobile-commerce throughout Thai society.

However, this study contains nine suggestions for sole proprietors who seek to develop an e-commerce business. These recommendations include: 1) Consider the structure and pattern of establishment in the business with sole proprietorship, 2) Take stock of your talents and skills before deciding to start a business, 3) Consider the skill of the operator when setting current prices, 4) Gage your potential in a management role, 5) Assess the underlying market and consumers, 6) Divide responsibility for the operation of the business, 7) Look at time management and continuity to help your business meet goals or save time, 8) Consider the cost of investment alongside the profit from the business, 9) Forecast future trends for your business, so the sole proprietorship can use more information to manage the business.

\section{Suggestion for Government Policy}

The government should create a policy to support sole proprietorships in various ways, such as lower taxes during a one-year period when the business is being established or help such entrepreneurs with market channel when have just launched their ventures.

\section{References}

Ali, M., \& Kurnia, S. (2010). Exploring interorganisational systems (IOS) adoption in Bahrain. Proceeding in 21st Australasian Conference on Information Systems (ACIS), December, 1-3, 2010. Queensland University of Technology, Brisbane, Australia.

Bank of Thailand. (2008). Electronic commerce. Retrieved July 30, 2014, from http://www.bot.or.th/Thai/ PaymentSystems/Others/eCommerce/Pages/eCommerce.aspx

Brown, S. (2001). Managing process technology-further empirical evidence from manufacturing plants. Technovation, 21(8), 467-478. http://dx.doi.org/10.1016/S0166-4972(00)00074-2

Business Research Sector. (2012). Export SMEs increasing by E-commerce. Export - Import Bank of Thailand. Retrieved July 10, 2014, from http://www.exim.go.th/doc/newsCenter/40894.pdf

Chammanee, P. (2011). Customer behavior to using facebook and responsibility strategies part online information affected to ticket order of Air Asian airline. Master Thesis, Master of Business and Administration, Burapha University.

Chonkrin, C. (2008). Business styles. Retrieved July 10, 2014, from http://202.29.52.57/ chanipa/file/s_02.ppt

Damanpour, F. (2001). E-business E-commerce evolution: Perspective and strategy. Managerial Finance, 27(7), 16-33. http://dx.doi.org/10.1108/03074350110767268

Electronic Transaction Department Agency. (2014). Thailand Internet User profile. Retrieved form http://www.etda.or.th/etda_website/files/system/IUP-pocketA5-050814.pdf

Entrepreneurs. (2005). The Basics of Sole Proprietorships. Retrieved July 30, 2014, from http://www.entrepreneur.com/article/77798

Feizollahi, S., Shirmohammadi, A., Safari, K. Z., \& Safari, K. M. (2014). Investigation the effect of internet technology on performance of services organizations with e-commerce orientations. Procedia-Social and 
Behavioral Sciences, 109, 605-609. http://dx.doi.org/10.1016/j.sbspro.2013.12.514

Fillis, I., \& Wanger, B. (2005). E-business development an exploratory investigation of the small firm. International Small Business Journal, 23(6), 604-634. http://dx.doi.org/10.1177/0266242605057655

Harpaz, I. (2002). Advantages of telecommuting for the individual, organization and society. Work Study, 51(2), 74-80.

Inc. (2010). How to Start a Sole Proprietorship. Retrieved July 29, 2014, from http://www.inc.com/guides/ 2010/10/how-to-start-a-sole-proprietorship.html

Internet World Stats Usage and Population Statistics. (2012). Internet Usage Statistics. Retrieved May 10, 2013, from http://www.internetworldstats.com/stats.htm

IRS. (2014). Sole Proprietorships. Retrieved July 29, 2014, from http://www.irs.gov/Businesses/SmallBusinesses-\&-Self-Employed/Sole-Proprietorships

Kasikron Research Center. (2013). 3G push E - commerce 2013 to Mobile increasing more than 25\%. K econ Analysis, 19(2381). Retrieved July 12, 2014, from http://ibrary.dip.go.th/multim6/edoc/2556/21973.pdf

Keawkityphong, L. (2013). The value network analysis of mobile commerce industry. Thammasart Business Journal, 36(139), 43-58

Kiyota, K., \& Okazaki, T. (2005). Foreign technology acquisition policy and firm performance in Japan, 1957-1970: Micro-aspects of industrial policy. International Journal of Industrial Organization, 23(7), 563-586. http://dx.doi.org/10.1016/j.ijindorg.2005.03.004

Kun, G. (2000). Obstacles to the growth of e-commerce. Retrieved July 30, 2014, from http://www.china.org.cn/english/2261.htm

MacGregor, R., \& Vrazalic, L. (2004). Chapter1 Introduction. E-Commerce in Adoption in SMEs: A Comparative Study of Wollongong (Australia) and Karlstad (Sweden). Retrieved July 8, 2014, from http:// business.uow.edu.au/content/groups/public/@web/@commerce/@econ/documents/doc/uow012275.pdf

Mansor, N., \& Abidin, A. F. A. (2010). The application of e-commerce among Malaysian small medium enterprises. European Journal of Scientific Research, 14(4), 591-605

Ministry of Foreign Affairs Business Handbook. (2011). Section 5: Starting a business in Thailand. Retrieved from http://www.thaiembassy.org/cairo/contents/files/business-20140108-044028-170042.pdf

National Economic and Social Office. (2012). Information report: Surveying E-commerce situation in Thailand 2011. Thailand, National Statistical Office.

National Electronics and Computer Technology Center (NECTEC). (2012). Report on the survey of Internet users in 2011. Retrieved August 18, 2013, from http://www.nectec.or.th/index.php?option=com contentandview $=$ articleandid $=2620 \% 3 \mathrm{~A}-2553$ andcatid $=213$ andItemid $=790$

National Information Center, The Ministry of Information and Communication. (2012). Important report, Explore the status of e-commerce in Thailand (2011). Retrieved August 18, 2013, from http://service.nso.go.th/nso /nsopublish/ download/files/ictDev53.pdf

National Statistic. (2012). Report of Internet user in 2011. Retrieved July 12, 2014, from http://service.nso.go.th/nso/nsopublish/themes/files/icthh56.pdf

Ongsakul, W., \& Kanitpong, T. (2007). Small business management. Thailand, I group Press.

Ortega, H. B., Martinez, J. J., \& Hoyos, M. J. M. (2008). B2C e-commerce acceptance: The moderation effect of gender. Communication of the IBIMA $6^{\text {th }} .104-112$. Retrieved July 12, 2014, from http://www.ibimapublishing.com/journals/CIBIMA/volume6/v6n16.pdf

Patil, H., \& Rajiv Divekar, B. (2014). Inventory management challenges for B2C e-commerce retailers. Procedia Economics and Finance, 11(2014), 561-571. http://dx.doi.org/10.1016/S2212-5671(14)00221-4

Pattanakit Accounting Tax and Training. (2013). Stronger and weakness of sole proprietorship of business. Retrieved July 12, 2014, from http://www.pattanakit.net/index.php?lay=show\&ac=article\&Id=538955943 $\&$ Ntype $=124$

Phecharaburanin, P. (2013). E-commerce and Thai society. Pathumwan Academic Journal, 3(7), 39-45

Ratprasatporm, P., \& Thienpreecha, K. (2002). Foreign investment in Thailand: Review of the current legislative regime. Retrieved from http://www.boi.go.th/english/download/business_analysis/26/foreign-investment- 
laws.pdf

Ratprasatporn, P., \& Thienpreecha, K. (2002). Foreign investment in Thailand: Review of the current legislative regime. Tilleke \& Gibbins International Ltd. Retrieved July 12, 2014, from http://www.boi.go.th/english/ download/business_analysis/26/foreign-investment-laws.pdf

Anubhav Reddy, N., \& Rajiv Divekar, B. (2014). A study of challenges faced by e-commerce companies in India and methods employed to overcome them. Procedia Economics and Finance, 11, 553-560. http://dx.doi.org/10.1016/S2212-5671(14)00220-2

Roders, S., \& Harris, A. M. (2003). Gender and e-commerce: An exploratory study. Journal of Advertising Research, 43(3), 322-329. http://dx.doi.org/10.1017/S0021849903030307

Santos, F. (2003). E-service Quality: A Model of Virtual Service Quality Dimensions. Managing Service Quality, $13(3), 233-246$.

Schimmel, K., Morris, R., \& Nicholls, J. (2005). Gender differences and e-commerce behavior and perception. ARRAY Development. Retrieved form http://www.arraydev.com/commerce/jibc/0306-01.htm

Sintrakranphon, N. (2008). Modern business in innovation era. Thailand, S. Asia Press.

Tokokoo. (2010). Advantages and disadvantages of e-commerce. Retrieved July 30, 2014, from http://tokokoo.com/2010/07/advantages-and-disadvantages-of-e-commerce/

Uphatumwiphanon, K. (2012). Special report E-commerce. TPSO Journal, 3(19), 4-5.

\section{Copyrights}

Copyright for this article is retained by the author(s), with first publication rights granted to the journal.

This is an open-access article distributed under the terms and conditions of the Creative Commons Attribution license (http://creativecommons.org/licenses/by/3.0/). 